\title{
KOMODIFIKASI BUDAYA DI ERA EKONOMI GLOBAL TERHADAP KEARIFAN LOKAL:

\author{
Studi Kasus Eksistensi Industri Pariwisata dan
} Kesenian Tradisional di Jawa Tengah
}

\author{
Agus Maladi Irianto \\ Universitas Diponegoro (Undip) Semarang \\ e-mail: ami.fibundip@gmail.com
}

\begin{abstract}
The culture commodification is the sale-purchase transaction of cultural objects through industrial process that was born along with the globalization era. The tourism industry is the child of globalization that produce cultural objects to be traded for the financial benefit. One form of the commodification cultural objects in the globalization era is the traditional arts. The problem is how the strategy needs to be developed so that the traditional arts as the subject of its supporting society's local wisdom is remain protected, but on the other hand it is expected to accomodate the demand of economic globalization that has conducted the culture commodification? With the aim to synergize the presence of traditional arts as the cultural identity of its supporting society and the tourism industry demands that conduct culture commodification, then through a field research using qualitative method, it resulted the following description. First, the culture commodification becomes a necessity in the global economy era that evolve in this era of postmodernity, especially it's marked by the growing of the tourism industry. Second, the culture commodification to the local wisdom can basically be solved by several strategies without marginalizing the supporting society of the local wisdom. Third, the existence of traditional arts as a cultural identity can be protected and revitalized from the demands of the culture commodification, as long as it is also developing a concept that is able to synergize the perception and responses of the supporting society to the demands of the tourism industry. Fourth, one of the most relevant concepts to accommodate the demands of the culture commodification is a concept that is commonly referred as the pseudo traditional art.
\end{abstract}

Abstrak: Komodifikasi budaya adalah transaksi jual beli benda budaya melalui
proses industri yang lahir seiring dengan era globalisasi. Industri pariwisata
adalah anak kandung globalisasi yang memproduksi benda budaya untuk
diperjualbelikan demi keuntungan secara finansial. Salah satu bentuk benda
budaya yang dikomodifikasi di era globalisasi adalah kesenian tradisional. Per-
masalahannya adalah, bagaimana strategi yang perlu dikembangkan agar
kesenian tradisional sebagai subjek kearifan lokal masyarakat pendukungnya
tetap telindungi, tetapi di sisi lain ia diharapkan bisa mengakomodasi tuntutan
globalisasi ekonomi yang telah melakukan komodifikasi budaya? Dengan tujuan
untuk mensinergikan antara keberadaan kesenian tradisional sebagai identitas
kultural masyarakat pendukung dan tuntutan industri pariwisata yang me-
lakukan komodifikasi budaya, maka melalui penelitian lapangan yang meng-
gunakan metode kualitatif telah menghasilkan gambaran sebagai berikut. 
Pertama, komodifikasi budaya menjadi keniscayaan di era ekonomi global yang berkembang di era pascamodernitas ini, terutama ditandai dengan kian berkembangnya industri pariwisata. Kedua, komodifikasi budaya terhadap kearifan lokal pada dasarnya dapat dipecahkan dengan sejumlah strategi tanpa harus memarjinalkan masyarakat pendukung kearifan lokal tersebut. Ketiga, keberadaan kesenian tradisional sebagai identitas kultural dapat terlindungi dan direvitalisasi dari tuntutan komodifikasi budaya, sepanjang dikembangkan suatu konsep yang mampu mensinergikan antara persepsi dan respons masyarakat pendukung dengan tuntutan industri pariwisata. Keempat, salah satu konsep yang paling relevan untuk mengakomodasi tuntutan komodifikasi budaya adalah konsep yang lazim disebut sebagai psedo traditional art.

Keywords: globalization; tourism industry; traditional art; cultural commodification

\section{A. Pendahuluan}

Globalisasi ekonomi pada dasarnya memberi gambaran tentang suatu kehidupan ekonomi secara global dan terbuka, tanpa mengenal batasan teritorial atau kewilayahan antara negara satu sama lain. Gambaran terbuka merujuk pada suatu kegiatan investasi perdagangan dunia secara bebas. Konsekuensi perdagangan bebas tersebut, menciptakan kawasan perdagangan yang makin luas dan menghilangkan hambatan-hambatan tidak lancarnya perdagangan internasional. Singkat kata, globalisasi ekonomi berarti adanya keharusan penghapusan seluruh batasan dan hambatan terhadap arus barang, jasa serta modal. ${ }^{1}$ Globalisasi ekonomi merupakan suatu proses kegiatan ekonomi dan perdagangan, dimana negara-negara di seluruh dunia menjadi satu kekuatan pasar yang semakin terintegrasi dengan tanpa rintangan batas teritorial negara. Globalisasi perekonomian mengharuskan penghapusan seluruh batasan dan hambatan terhadap arus modal, barang dan jasa. ${ }^{2}$

Irianto mengatakan, globalisasi merupakan gambaran tentang penciutan dan penyeragaman dunia. Dengan adanya perkembangan teknologi informasi saat ini telah mengubah kebudayaan sebagian besar masyarakat dunia, baik yang tinggal di perkotaan maupun di pedesaan. Masyarakat di seluruh dunia

${ }^{1}$ Agus Maladi. Irianto, "Kesenian Daerah dan Globalisasi, Sebuah Konsep Menuju Ketahanan Budaya”. Dipresentasikan pada Saresehan Pengkajian Pemeliharaan dan Pengembangan Kesenian serta Kebudayaan Daerah Provinsi Jawa Tengah. Diselenggarakan Badan Kesbangpol dan Linmas Prov. Jateng di Kabupaten Kendal dan Batang, tanggal 21 \& 30 Juli, 2009, h. 1-10.

2Muhammad Shiddiq A.A. Aris, "Dampak Perekonomian Global terhadap Perekonomian Lokal", dalam laman http://muhammadshiddiq-aa.blogspot.co.id/2015/10/dampak-perekonomian-globalterhadap. html. Diunduh pada 19 Februari 2016. 
saat ini telah melakukan transaksi ekonomi dan memperoleh informasi dalam waktu singkat berkat teknologi satelit dan komputer. Kebudayaan dalam era globalisasi tidak sekadar disikapi sebagai keseluruhan pola perilaku, pengetahuan, dan pola pikir kelompok sosial masyarakat secara mapan. Kebudayaan bukan dipandang sebagai suatu realitas kebendaan yang selalu tetap, tetapi kebudayaan di era globalisasi ekonomi telah membentuk realitas yang selalu diproduksi dan direproduksi secara terus menerus, yang kemudian melahirkan identitas-identitas baru. ${ }^{3}$

Identitas, di era globalisasi ekonomi ini bukanlah suatu wujud yang sudah ada sejak semula dan tetap bertahan dalam suatu esensi yang abadi. Sedangkan dilihat dari aspek ruang, ia juga bukan hanya satu atau tunggal, tetapi terdiri dari berbagai lapis-lapis identitas. Lapis-lapis identitas itu tergantung pada peranperan yang dijalankan, keadaan objektif yang dihadapi, serta ditentukan pula dari cara menyikapi keadaan dan peran tersebut. ${ }^{4}$ Identitas bukanlah suatu yang selesai dan final, tetapi merupakan suatu kondisi yang selalu disesuaikan kembali, sifat yang selalu diperbarui, dan keadaan yang dinegosiasi terusmenerus, sehingga wujudnya akan selalu tergantung dari proses yang membentuknya. Identitas pada saat ini menjadi semakin pudar dengan kepentingan-kepentingan yang justru lebih mengemuka. Meminjam istilah Smith, ${ }^{5}$ perkembangan sosial saat ini, pada dasarnya telah melampaui pemikiran modernitas (yang ditandai dengan munculnya industri barang dan jasa) menuju pemikiran pascamodernitas yang cenderung lebih diorganisasikan oleh seputar konsumsi budaya dan permainan media massa.

Globalisasi ekonomi dalam konteks masyarakat Indonesia saat ini, tumbuh beriringan dengan perkembangan konsumsi budaya. Pertumbuhan itu membentuk transformasi kapitalisme konsumsi yang ditandai dengan menjamurnya pusat perbelanjaan bergaya seperti shopping mall, industri waktu luang, industri

${ }^{3}$ Agus Maladi Irianto, "Media dan Multikulturalisme" dalam Multikulturalisme Yogyakarta dan Identitas Keindonesiaan (Editor: Sri Rahayu Budiarti dan Muslimin A.R. Effendy) (Jakarta: Departemen Kebudayaan dan Pariwisata Republik Indonesia, 2009), h. 31-64.

${ }^{4}$ Agus Maladi Irianto, "Pencarian Identitas dan Integrasi Kebudayaan pada Masyarakat Multikultural”. Dipresentasikan pada Seminar Keanekaragaman Budaya Sebagai Perekat Keutuhan Bangsa Menuju Indonesia Baru. Diselenggarakan Fakultas Sastra UNDIP di Semarang, 8 September.2005, h. 1-15.

5Philip Smith, Cultural Theory: An Introduction (Oxford \& Massachusetts: Blackwell Publishers, 2001), h. 214-232. 
mode atau fashion, industri kecantikan, industri kuliner, industri nasihat, industri gosip, kawasan huni mewah, apartemen, iklan barang-barang mewah, makanan instan (fast food), serta reproduksi dan transfer gaya hidup melalui iklan dan media. ${ }^{6}$ Sedangkan permainan media masa, di era globalisasi ekonomi akan sejalan dengan sejumlah kepentingan yang melatarbelakangi terkonstruksinya isi media tersebut. Terkonstruksinya isi media pada perkembangan saat ini dapat diperhatikan pada interaksi dan negosiasi antar-individu yang mengendalikan media tersebut.7 Sebagai contoh, kehadiran industri penyiaran televisi di Indonesia saat ini, nyaris menyergap setiap warga masyarakat sejak bangun pagi hingga tidur kembali. Ia telah membentuk pengetahuan tentang suatu realitas yang serba cepat, sekaligus memuat strategi komunikasi agar mampu memelihara atau mengubah sikap atau pendapat sasaran demi kepentingan sumber pembuat strategi. Sehingga, dapat dikatakan bahwa televisi ini cenderung mengajak audience-nya agar patuh kepada pihak yang menguasai modal komunikasi, baik dalam konteks politik maupun ekonomi.8

Salah satu isu yang menonjol dalam era globalisasi adalah munculnya istilah komodifikasi. Komodifikasi adalah proses terjadinya perubahan barang atau layanan yang sebelumnya mengikuti aturan sosial non-pasar menjadi suatu subjek yang mengikuti aturan pasar. ${ }^{9}$ Komodifikasi merupakan salah satu bentuk kapitalisme global mengakumulasi kapital, komodifikasi telah mentransformasi nilai guna menjadi nilai tukar yang sifatnya komersial. ${ }^{10}$

Sejalan dengan sejumlah deskripsi tersebut, globalisasi ekonomi telah memberi tantangan perkembangan kebudayaan di Indonesia. Globalisasi ekonomi, memicu setiap produk-produk budaya berkontestasi secara terbuka dan kreatif. Dampak dari globalisasi ekonomi juga terdestribusi ke sejumlah relasi kehidupan masyarakat, tidak terkecuali terhadap eksistensi kesenian 64.

${ }^{6}$ Agus Maladi Irianto, "Media dan Multikulturalisme" dalam Multikulturalisme Yogyakarta ..., h. 31-

${ }^{7}$ Agus Maladi Irianto, "Mass Media Reality In Indonesia: The Local Wisdom That Were Marginalized By The TV Broadcast". Dipresentasikan dalam The International Seminar on Education as Media of Socialization and Enculturation of Local Culture. Held by the Graduate School of Education and Human Developoment, Nagoya University, Juni 25th. 2013, h. 1-13.

8 John Fiske, Television Culture (London: Routledge., 1987), h. 43-49.

${ }^{9}$ Peter H. Gleick, etal., The New Economy of Water: The Risk and Benefits of Globalization and Privatization of Fresh Water (California: Pasific Institute, 2002), h. 1-5.

${ }^{10}$ Adorno dan Horkheimer, The Culture Industry Enlightenment as Mass Deception (London: Verso, 1979), h. 12-17. 
tradisional yang selama ini dianggap sebagai identitas kultural bagi masyarakat pendukungnya. ${ }^{11}$ Kesenian tradisional yang selama ini menjadi ekspresi masyarakat pendukung untuk menciptakan keserasian antara manusia dan lingkungannya, harus dituntut bersaing dengan produk-produk budaya lain secara terbuka. Kesenian tradisional telah dijadikan benda budaya yang diproduksi oleh suatu industri secara massal demi keuntungan secara finansial. Kesenian tradisional yang semula sebagai subjek pengetahuan, kebijakan, dan kearifan lokal masyarakat pendukungnya, kemudian berubah menjadi objek berupa benda yang harus diperjualbelikan melalui proses produksi budaya. ${ }^{12}$ Dari sinilah lahir komodifikasi budaya berupa transaksi jual beli benda budaya berupa kesenian tradisional. Melalui proses industri yang menuntut keuntungan secara finasial, eksistensi kesenian tradisional dikemas menjadi benda budaya yang harus mengikuti aturan pasar.

Dengan masuknya arus globalisasi ke Indonesia, kesenian tradisional menghadapi tantangan global, karena globalisasi juga merupakan bentuk penetrasi nilai baru yang melahirkan perangkat-perangkat praktis. Lahirnya perangkat-perangkat praktis yang berbasis informasi, komunikasi, dan teknologi melahirkan industrialisasi yang selalu mengarah pada orientasi pasar. Dengan adanya perangkat-perangkat tersebut, memproduksi dan mereproduksi ekspresi kebudayaan sebanyak-banyaknya di era globalisasi menjadi suatu keniscayaan. Dengan kekuatan industrialistik dan kapitalistik, maka proses produksi secara massal tidak terhindarkan, termasuk memproduksi kesenian tradisional.

Di era globalisasi, terutama dengan adanya industri pariwisata, para pelaku kesenian tradisional ditantang memenuhi tuntutan pasar. Akan tetapi, sebagai akibat pertumbuhan industri pariwisata yang tidak terkendali, terjadilah perusakan alam, pencemaran seni budaya, objek wisata. Lebih dari itu, masyarakat yang berada di sekitar objek wisata akan termajinalisasi identitas dan kepribadiannya. Di Bali misalnya, para seniman tradisional yang men-

\footnotetext{
${ }^{11}$ Agus Maladi Irianto, dkk, "Model-model Pengembangan Atraksi Kesenian Tradisional Wonosobo, Sebagai Strategi Pemahaman Wawasan Wisata Masyarakat Lokal", Laporan Penelitian (Semarang: LPPM Undip, 2010), h. 21-26. Agus Maladi Irianto, dkk., "Mengemas Kesenian Tradisional dalam Bentuk Industri Kreatif, Studi Kasus Kesenian Jathilan”, Laporan Penelitian (Semarang: LPPM Undip, 2015), 19-25.

${ }^{12}$ Sri Suneki, “Dampak Globalisasi terhadap Eksistensi Budaya Daerah”. Jurnal Ilmiah CIVIS, Vol. 2I No. 1, 2012, h., 307-319.
} 
dukung industri pariwisata harus naik truk dan menerima upah yang relatif rendah, meski mereka melakukan pertunjukan di hotel-hotel berbintang. ${ }^{13}$ Dengan menanggalkan nilai kesakralan yang selama ini diwariskan turuntemurun, para pelaku kesenian tradisional harus melayani pemesanan pembeli. Lahirlah produk-produk seni secara massal yang tidak didasarkan atas ide dan nilai-nilai yang selama ini melekat pada si pelaku kesenian tradisional tersebut. Produk-produksi seni secara massal itu dijual secara murah dan cepat. Sebagai contoh, dengan adanya alat teknologi seperti taperecorder, TV, video player, VCD, DVD, membawa dampak pada bentuk pertunjukan kesenian tradisional yang semula utuh dan sakral, menjadi kemasan yang padat, ringkas, dan menghibur.

Dari sinilah gerakan komodifikasi kesenian tradisional di Indonesia tidak bisa dihindari. Salah satu anak kandung yang dilahirkan arus globalisasi adalah industri pariwisata. Industri pariwisatalah yang membentuk komodifikasi budaya kesenian tradisional, karena dengan ditandai tuntutan turisme dan pariwisata kesenian tradisional harus diperjualbelikan.14 Dengan berkembangnya turisme dan pariwisata, menurut Kayam ${ }^{15}$ keberadaan kesenian tradisional saat ini telah menjadi bagian dari komersialisasi budaya. Globalisasi ekonomi bertolak dari kegiatan di sektor pariwisata menuntut adanya hiburan berupa pertunjukan kesenian tradisional yang sejalan dengan daya tarik objek wisata, dan lazim disebut sebagai atraksi wisata.

Tuntutan dunia pariwisata itulah, mengubah cara pandang masyarakat pendukung kesenian tradisional terhadap keberadaan kesenian tradisional. Ia tidak hanya disikapi sebagai identitas kultural yang mengakomodasi tuntutan ritual masyarakat pendukungnya semata. Keberadaan kesenian tradisional saat ini juga dituntut menjadi komoditi hiburan yang memuat unsur komersial. Dengan demikian, eksistensi kesenian tradisional di era globalisasi ekonomi ini menunjukkan gambaran tentang benturan antara nilai tradisional yang mengabdi pada harmoni, keselarasan, dan mistis dengan nilai modern yang

${ }^{13}$ Agus Muriawan Putra, "Identitas \& Komodifikasi Budaya dalam Pariwisata Budaya Bali”, Jurnal Analisis Pariwisata., Vol. 8, No. 2, 2008, h. 7-16.

${ }^{14}$ Agus Maladi Irianto, "Pariwisata Jawa Tengah, Diskusi tentang Manusia dan Kebudayaan". Jurnal Ilmiah Universitas Trisakti PARIWISATA, Vol. 15 No.1, 2010, h. 13-18. h. 7-15.

15Umar Kayam, "Seni Pertunjukan dan Sistem Kekuasaan”. Jurnal Seni GELAR. Vol. 2 No. 1, 1999, 
cenderung kapitalistik. ${ }^{16}$ Untuk itulah, idealnya industri pariwisata mampu sinergis dengan keberadaan kesenian tradisional. Seperti yang telah diungkapkan Swarbrooke bahwa industri pariwisata semestinya tidak hanya berdimensi ekonomi semata tetapi juga terintegrasi dalam dimesi lingkungan dan sosial. ${ }^{17}$

Pertanyaannya adalah, bagaimana mensinergikan tuntutan globalisasi terutama komodifikasi budaya industri dunia pariwisata- dengan pengembangan kesenian tradisional sebagai bagian dari atraksi wisata? Bagaimana strategi yang perlu dikembangkan agar kesenian tradisional sebagai identitas kultural atau subjek kearifan lokal masyarakat pendukungnya tetap telindungi, tetapi ia juga diharapkan bisa mengakomodasi tuntutan globalisasi ekonomi yang telah melakukan komodifikasi budaya?

Untuk menjawab pertanyaan tersebut, telah dilakukan penelitian lapangan di Kabupaten Wonosobo dan Kabupaten Magelang, Provinsi Jawa Tengah. Alasan pemilihan kedua lokasi tersebut adalah sebagai berikut. Pertama, kedua kabupaten ini mempunyai objek wisata andalan bagi industri Pariwisata Jawa Tengah Kabupaten. Kabupaten Wonosobo misalnya, yang menyimpan objek wisata alam Dieng, sementara Kabupaten Magelang mempunyai objek wisata Candi Borobudur yang keduanya sudah cukup dikenal wisatawan, baik di dalam negeri maupun wisatawan luar negeri. Kedua, di keduakedua kabupaten ini mempunyai ratusan kesenian tradisional yang hingga sekarang masih aktif dan berkembang. Kabupaten Wonosobo misalnya, mempunyai sejumlah kesenian tradisional (1070 jenis kesenian tradisional), sedangkan di Kabupaten Magelang ada 1156 jenis kesenian tradisional. ${ }^{18}$

\section{B. Metode Penelitian}

Tujuan penelitian ini, pertama memberikan wawasan baru tentang strategi dan pengembangan kesenian tradisional sejalan dengan tuntutan dunia pariwisata. Kedua, menemukan model-model alternatif melindungi kesenian

\footnotetext{
16Aan Kurniawan, "Dampak Perekonomian Global terhadap Perekonomian Domestik." Dalam http://aankurniawan-astra.blogspot.co.id/2015/10/dampak-perekonomian-global-terhadap.html. Diakses 21 Februari 2016.

17J. Swarbrooke, Sustainable Tourism Management (New York: CABI Publishing is division of CAB International 1998), h. 31.

${ }^{18}$ Agus Maladi Irianto, dkk, "Model-model Pengembangan Atraksi Kesenian Tradisional Wonosobo..., h. 18-20. Agus Maladi Irianto, dkk., “Mengemas Kesenian Tradisional ..., h. 15-16.
} 
tradisional sebagai identitas kultural masyarakat pendukung, tetapi tetap sinergis dengan tuntutan globalisasi ekonomi yang terekspresikan pada dunia pariwisata. Untuk mendukung tujuan kegiatan tersebut, maka dilakukan penelitian lapangan untuk mengkaji secara komprehensif tentang persepsi dan respons masyarakat pendukung terhadap keberadaan kesenian tradisional dan tuntutan atraksi seni dalam dunia kepariwisataan. Melalui penelitian lapngan juga dilakukan penggalian model-model pengembangan kesenian tradisional yang sejalan dengan tuntutan turisme dan dunia pariwisata, tanpa harus memarjinalkan kesenian tradisional dari masyarakat pendukungnya.

Penelitian dengan pendekatan kualitatif iniyang berusaha memahami secara mendalam dan holistik terhadap sejumlah fenomena yang dipelajari dan bukan untuk menguji hepotesis yang diajukan berdasarkan model rumus-rumus statistik.Untuk mendapatkan data tersebut, langkah penelitian yang telah dilakukan adalah dengan cara observasi, wawancara mendalam, dan Focus Group Discussion (FGD). Observasi dilakukan untuk mendeskripsikan gambaran riil di lapangan tentang kondisi kesenian tradisional dan objek wisata di lokasi kajian. Sedangkan kegiatan wawancara dan FGD dilakukan terhadap sejumlah informan untuk mendapatkan gambaran secara komprehensif tentang persepsi dan respons, padangan, sikap, harapan mereka terhadap keberadaan kesenian tradisional dan industri pariwisata. Para informan tersebut di antaranya adalah para praktisi dunia wisata, tokoh masyarakat, tokoh agama, serta tokoh-tokoh strategis lainnya.

Hasil observasi, wawancara mendalam, dan FGD tersebut dianalisis ke dalam model-model kategori, pembandingan, dan kekontrasan dan kemudian menginterpretasikannya. ${ }^{19}$ Interpretasi data dilakukan secara sistemik yaitu memahami suatu fakta/data dengan mempertimbangkan faktor-faktor lain yang terkait di dalamnya. Sedang untuk memahami faktor-faktor yang saling terkait dari data yang diperoleh tersebut, dikembangkan berdasarkan pada kerangka pemikiran masyarakat yang dipelajari bukan didasarkan pada ukuran peneliti. ${ }^{20}$

\footnotetext{
${ }^{19}$ Lihat John W. Creswell, Research Design. Qualitative \& Quantitative Approaches (USA: SAGE Publication, 1994), h. 153-154.

${ }^{20}$ Norman K. Denzin \& Yvonna S. Lincoln, eds., Handbook of Qualitative Research (USA: SAGE Publication., 1994), h. 43-45.
} 


\section{Hasil dan Pembahasan}

Berdasarkan hasil penelitian yang telah dilakukan, pada dasarnya dapat dideskripsikan tentang komodifikasi budayadi era ekonomi global terhadap kearifan lokal. Dengan melakukan studi kasus eksistensi industri pariwisata dan kesenian tradisionaldi Kabupaten Wonosobo dan Magelang Provinsi Jawa Tengah menghasilkan sejumlah deskripsi. Deskripsi tersebut di antaranya adalah: (1) gambaran umum industri pariwisata dan kesenian tradisional di lokasi kajian; (2) persepsi dan respons masyarakat pendukung terhadap kesenian tradisional dan industri pariwisata; dan (3) strategi pengembangan kesenian tradisional dan tuntutan industri pariwisata. Untuk menjelaskan masing-masing deskripsi itu, dapat diuraikan sebagai berikut.

\section{Gambaran Umum Industri Pariwisata dan Kesenian Tradisional di Lokasi Kajian}

Seperti telah diungkapkan pada uraian di atas bahwa lokasi penelitian lapangan telah di Kabupaten Wonosobo dan Kabupaten Magelang Provinsi Jawa Tengah. Kedua kabupaten ini sama-sama menjadi bagian wilayah Karesidenan Kedu. Baik Kabupaten Wonosobo maupun Magelang terletak di antara sejumlah gunung dan pegunungan. Kabupaten Wososobo misalnya, dikelilingi Gunung Sindoro, Sumbing, Prahu, Bismo, serta Pegunungan Telomoyo, Tampomas, serta Songgoriti. Sedangkan Kabupaten Magelang berada di cekungan sejumlah rangkaian pegunungan, di bagian timur terdapat Gunung Merbabu dan Gunung Merapi, di bagian barat terdapat Gunung Sumbing, dan di bagian barat daya terdapat rangkaian Pegunungan Menoreh. Oleh karena letaknya di antara sejumlah pegunungan itulah, maka kesuburan tanah kedua kabupaten ini amat tinggi. Kesuburan tanah itu sangat berpengaruh terhadap potensi pertanian, sehingga dunia pertanian merupakan sumber penghasilan utama bagi mayoritas warga masyarakat kedua kabupaten tersebut. ${ }^{21}$

Di sisi lain, kedua kabupaten tersebut mempunyai destinasi wisata yang cukup dikenal oleh para wisatawan, baik wisatawan yang berada di dalam negeri maupun luar negeri.Kabupaten Wonosobo misalnya, mempunyai objek

${ }^{21}$ Agus Maladi Irianto, dkk, "Model-model Pengembangan Atraksi Kesenian Tradisional Wonosobo..., h. 18-20. Agus Maladi Irianto, dkk., “Mengemas Kesenian Tradisional ..., h. 15-16. 
pariwisata andalan Provinsi Jawa Tengah yakni dataran tinggi Dieng. Di dataran tinggi ini, selain berhawa sejuk juga terdapat Telaga Warna, Telaga Pengilon, Gua Semar, Kawah Sikendang, Tuk Bimolukar, dan beberapa situs candi purbakala yang dibangun pada abad ke-8 Masehi sekaligus merupakan pusat penyebaran agama Hindu pertama di Jawa Tengah. ${ }^{22}$ Demikian pula di Kabupaten Magelang, terdapat objek wisata andalan, yakni Candi Borobudur.Objek wisata Candi Borobudur, sebuah mahakarya peninggalan Dinasti Syailendra yang kini menjadi kebanggaan Indonesia dan telah mendapat perlindungan dari UNESCO sebagai warisan dunia (World Heritage).

Selain dua objek wisata andalan, di kedua kabupaten tersebut juga menyimpan sejumlah objek wisata lain. Di sekitar dataran tinggi Dieng Kabupaten Wonosobo terdapat empat kelompok candi yang menggunakan nama tokoh-tokoh pewayangan, yaitu kelompok Candi Dwarawati dan Parikesit, kelompok Candi Setyaki, Ontorejo, Petruk, Nala Gareng, dan Nakula-Sadewa, serta kelompok Candi Arjuna, Semar, Sembodro, Puntadewa, dan Srikandi.23 Demikian pula di sekitar Candi Borobudur, terdapat sejumlah candi lain seperti Candi Mendut, Candi Pawon, Candi Ngawen, Candi Canggal atau Candi Gunungwukir, Candi Selogriyo, Candi Gunungsari, Candi Lumbung, Candi Pendem, dan Candi Asu. ${ }^{24}$ Kabupaten Wonosobo juga memiliki objek wisata seperti Telaga Menjer, agro wisata Tambi, Telaga Bedakah, Gua Angin. Gua Lawa, Sendang Surodilogo, Gantung dan Waduk Wadaslintang. Sedangkan di Kabupaten Magelang juga terdapat objek wisata Punthuk Setumbu, Grojokan Kedung Kayang, Air Terjun Sekarlangit, dan Ketep Pass.

Berdasarkan wawancara dengan sejumlah informan, sejumlah objek wisata di kedua kabupaten tersebut diminati sejumlah wisatawan sekaligus menjadi sasaran destinasi pariwisata Jawa Tengah. Dengan dijadikan sasaran destinasi pariwisata Jawa Tengah, itulah industri pariwisata mempunyai pengaruh yang signifikan terhadap pendapatan asli daerah (PAD) di kedua kabupaten ini.25 Harian Suara Merdeka ${ }^{26}$ memberitakan bahwa sektor

${ }^{22}$ Agus Maladi Irianto, dkk, "Model-model Pengembangan Atraksi...”, h. 17.

${ }^{23}$ Ibid., h. 32-33.

${ }^{24}$ Agus Maladi Irianto, dkk, “Mengemas Kesenian Tradisional ..., h. 45-49.

${ }^{25}$ Widya Karisma \& Abidin Lating." Analisis Peran Industri Pariwisata Terhadap Pendapatan Asli Daerah Kabupaten Wonosobo". Jurnal Ilmiah FEB Unibraw Karisma. No. 1 Vol. 3, 2013, h. 1-13. Subari, "Pengaruh Pemanfaatan Lingkungan Obyek Wisata Candi Borobudur Terhadap Ekonomi Masyarakat di Sekitarnya", Thesis (Yogyakarta: UGM, 2007), h. 75-76. 
pariwisata pada tahun 2015 lalu telah menyumbang PAD Kabupaten Wonosobo hingga Rp. 3 milyar dan tercatat ada sekitar 870 ribu wisatawan membeli retribusi di berbagai objek wisata di kabupaten tersebut. Kendati di kedua kabupaten tersebut terdapat sejumlah destinasi pariwisata dan telah dianggap sebagai pemberi kontribusi bagi PAD, tetapi ternyata belum berdampak secara signifikan terhadap kesejahteraan masyarakat di sekitarnya. Sebagai contoh, kontribusi pariwisata Borobudur terhadap PAD Pemerintah Kabupaten Magelang, ternyata belum dirasakan oleh masyarakat setempat, bahkan mereka justru masih dililit oleh kemiskinan dan pengangguran.27

Seiring dengan berkembanganya industri pariwisata, di kedua kabupaten ini juga menyimpan sejumlah jenis kesenian tradisional yang selama ini menjadi kebutuhan integratif masyarakat setempat. Kabupaten Wonosobo misalnya, mempunyai jenis-jenis kesenian tradisional seperti Lengger, angguk, bangilun, dan bundengan. Lengger, Badutan, Cepetan, Bambu Runcing, Bangilun, Bugisan, Cekak Mondol, Dayakan, Dagelan Punokawan, Madyo Pitutur, Panembromo, Pentulan, Srandul, Thek Ethek Kampling, Turonggo Baras. Berdasarkan data di lapangan tercatat ada sekitar 1070 jenis kesenian tradisional yang tersebar di 12 kecamatan (Kalibawang, Sapuran, Selomerto, Sukoharjo, Wadaslintang, Kejajar, Mojotengah, Garung, Leksono, Wonosobo, Kaliwiro, dan Watumalang) di Kabupaten Wonosobo. Sedangkan Kabupaten Magelang yang terdiri 21 kecamatan (Bandongan, Borobudur, Candimulyo, Dukun, Grabag, Kajoran, Kaliangkrik, Mertoyudan, Mungkid, Muntilan, Ngablak, Ngluwar, Pakis, Salam, Salaman, Sawangan, Secang, Srumbung, Tegalrejo, Tempuran, dan Windusari) mempunyai hingga bulan Juli 2015, sedikitnya ada 1156 jenis kesenian tradisional. Jenis-jenis kesenian tradisional tersebut adalahTopeng Ireng, Soreng, Wayang Orang, Kubrosiswo, Jathilan, Dayakan, Topengan, Ketoprak, Prajuritan, Jelantur, Warokan, Dolalak, Srandul, Lengger, Gangsir Ngentir, Reog, Sholawatan, Ande-ande Lumut, Gatholoco, Rodhat, Manasuka, Langentoyo, Kuntulan, Cekok Mondol, Balilele, dan Cakarlele.

Selain kesenian tradisional, sejumlah tradisi dan ritual juga diselenggarakan masyarakat lokal untuk mendukung industri pariwisata di kedua kabupaten

${ }^{26}$ Suara Merdeka, "Sektor Pariwisata Sumbang PAD Rp 3 M", Edisi 13 Januari 2016. http://berita.suaramerdeka.com/smcetak/sektor-pariwisata-sumbang-pad-rp-3-m/. Diunduh tanggal 21 Februari 2016.

${ }^{27}$ Subari, "Pengaruh Pemanfaatan Lingkungan Obyek Wisata Candi Borobudur terhadap Ekonomi Masyarakat di Sekitarnya”, Thesis (Yogyakarta: UGM, 2007), h. 75-76. 
tersebut. Misalnya, tradisi ngruwat rambut gembel dan tradisi baritan lazim dijadikan atraksi wisata di Kabupaten Wonosobo. Sedangkan atraksi wisata yang berkaitan dengan tradisi di Kabupaten Magelang di antaranya adalah tradisi suran dan tradisi gombakan. Sejumlah tradisi itu pada dasarnya merupakan bagian dari identitas kultural masyarakat yang sekaligus menjadi kearifan lokal berkaitan erat lingkungan dunia pertanian. Melalui tradisi tersebut, tersimpan pesan-pesan kultural berupa gagasan, abstraksi, sikap, maupun kepercayaan dan pengalaman masyarakat di kedua kabupaten yang mayoritas berlatar belakang dunia pertanian. ${ }^{28}$

Berdasarkan hasil penelitian lapangan, kendati di kedua kabupaten tersebutmempunyai banyak destinasi wisata dan sekaligus juga kaya akan kesenian tradisional, tetapi belum seimbang dengan nilai manfaat yang dirasakan masyarakat lokal yang tinggal di sekitar destinasi wisata. Lebih dari itu, posisi tawar masyarakat lokal sebagai pemilik kesenian tradisional dan pelaku tradisi yang dijadikan atraksi wisata relatif lemah dibandingkan dengan para produser industri pariwisata di wilayah setempat.29 Posisi tawar yang lemah disebabkan beberapa hal, pertama, jumlah produser industri pariwisata relatiflebih sedikit dibandingkan jumlah seniman seni tradisi. Kedua, banyaknya jumlah seniman atau organisasi kesenian tradisional ternyata di antara mereka justru saling bersaing secara kurang sehat. Ketiga, karya seni yang dihasilkan oleh seniman atau organisasi kesenian tradisional pada umumnya relatif sama, jarang di antara mereka memiliki karya unik dan sulit ditiru seniman lain. Keempat, produser industri pariwisata dengan mudah berpindah dari satu seniman ke seniman lain tanpa mengurangi kualitas paket wisata budaya mereka. Kelima, produser industri pariwisata memiliki informasi relatif lengkap mengenai kesenian tradisional di suatu wilayah maupun tentang pasar wisata budaya, sementara seniman kesenian tradisional justru kurang memiliki kapasitas seperti yang dimiliki produser industri pariwisata.

\section{Persepsi dan Respons Masyarakat Pendukung terhadap Kesenian Tradisional dan Industri Pariwisata}

Pada uraian di atas telah disebutkan bahwa Kabupaten Wonosobo dan Magelang menyimpan banyak jenis kesenian tradisionalyang didukung oleh

\footnotetext{
${ }^{28}$ Agus Maladi Irianto, dkk, “Model-model Pengembangan Atraksi Kesenian Tradisional ..., h. 57. Agus Maladi Irianto, dkk., "Mengemas Kesenian Tradisional ...", h. 21-24.

${ }^{29} \mathrm{Ibid}$.
} 
masyarakat yang aktivitas kesehariannya di bidang pertanian. Mereka adalah suatu kelompok masyarakat yang terdiri dari orang-orang yang tinggal di pedesaan mengendalikan secara efektif sebidang tanah, dan mereka sejak lama terikat dalam suatu ikatan tradisi dan perasaan. Dengan terus memegang tradisi dan perasaan itulah, maka mereka menganggap bahwa tanah dan dirinya merupakan bagian yang saling berhubungan erat. Mereka bekerja di sawah bukan semata-mata untuk mencari keuntungan, tetapi lebih cenderung untuk mencukupi keperluan keluarganya yang sederhana atau hak untuk hidup pada paras subsistens. ${ }^{30}$ Sebagai masyarakat petani, maka kebudayaan yang tercermin melalui norma-norma dan tradisi erat berhubungan dengan dunia pertanian. ${ }^{31}$ Bentuk keterikatan terhadap norma-norma dan tradisi tersebut, salah satu di antaranya tertuang melalui persepsi dan respons mereka terhadap keberadaan kesenian tradisional. Persepsi dan respons masyarakat pendukung terhadap keberadaan kesenian tradisional tersebut pada dasarnya dipahami sebagai bentuk penyikapan, gagasan-gagasan, dan pemberian makna berdasarkan seluruh pengetahuan yang mereka dimiliki. ${ }^{32}$

Sikap, gagasan, serta pemaknaan berdasarkan pengetahuan yang dimiliki masyarakat pendukung tersebut, akan menentukan tumbuh dan berkembangnya kesenian tradisional. Selama pengetahuan masyarakat pendukung yang berlatar belakang petani beranggapan bahwa kesenian tradisional mampu mengakomodasi kebutuhan integratif mereka, maka eksistensi kesenian tradisional akan tetap dipertahankan. Kebutuhan integratif pada dasarnya melengkapi kebutuhan biologis dan kebutuhan sosial yang melekat pada setiap manusia secara universal. Kebutuhan integratif lazim juga disebut sebagai kebutuhan simbolik. Kebutuhan ini merepresentasikan bahwa manusia adalah makhluk budaya yang terpancar dari sifat-sifat dasar manusia sebagai makhluk pemikir, bermoral, dan bercita rasa. Kebutuhan integratif berfungsi untuk mengintegrasikan berbagai kebutuhan menjadi suatu sistem yang dibenarkan secara moral, dipahami akal pikiran, dan diterima cita rasa. ${ }^{33}$ Kesenian merupakan kebutuhan integratif manusia dalam rangka meningkatkan dan melangsungkan taraf hidup. Betapapun sederhana kehidupan manusia, di sela-sela memenuhi

${ }^{30}$ Agus Maladi Irianto, dkk, “Mengemas Kesenian Tradisional ..., h. 24-26.

${ }^{31}$ R. Redfield, Masyarakat Petani dan Kebudayaan (terj.) (Jakarta: YIIS, 1985), h. 83-85.

${ }^{32}$ Agus Maladi Irianto, Erotika Petani Jawa Memuja Dewi: Tayub, Antara Ritualitas dan Sensualitas (Semarang: Lengkongcilik Press, 2005b), h. 153.

33Victor Turner, The Ritual Process (New York: Cornel University Press., 1986), h. 50-52. 
kekebutuhan biologis atau kebutuhan primer senantiasa mencari peluang untuk mengungkapkan dan memanfaatkan keindahan melalui kesenian. Demikian pula keberadaan kesenian tradisional, ia ada dan berkembang, dibakukan melalui tradisi-tradisi suatu masyarakat, serta untuk menopang dan mempertahankan kolektivitas sosial. ${ }^{34}$

Jika kesenian tradisional selama ini dibakukan melalui tradisi demi mempertahankan kolektivitas sosial masyarakat pendukungnya, maka di dalamnya juga menyimpan berbagai makna dan pesan-pesan kultural. Pesanpesan kultural tersebut, dapat berupa gagasan, abstraksi, sikap, maupun kepercayaan dan pengalaman masyarakat pendukungnya. Sebagai masyarakat yang berlatar belakang dunia pertanian, maka pesan-pesan kultural yang tersimpan pada kesenian tradisional tersebut akan berupa keyakinan yang berkaitan erat dengan dunia pertanian. Masyarakat petani pedesaan mempercayai bahwa manusia bisa mempengaruhi tanaman agar menjadi subur yakni dengan menyelenggarakan ritual yang melambangkan kesuburan. Salah satu bentuk ritual yang melambangkan kesuburan akan diekspresikan dalam pertunjukan kesenian tradisional. 35

Sebagai bagian dari prosesi ritual, maka pertunjukan kesenian tradisional akan terikat pada aturan dan norma yang telah disepakati secara turun temurun. Misalnya, menyangkut pemilihan waktu yang tepat untuk penyelenggaraan pertunjukan tersebut. Dengan latar belakang masyarakat pendukung kesenian tradisional yang orientasi kulturalnya pada dunia pertanian, maka waktu yang tepat untuk menyelenggarakan pertunjukan adalah di antara musim panen atau musim tanam. ${ }^{36}$ Pemilihan waktu ini berkaitan erat dengan kepercayaan rasa syukur terhadap Dewi Sri yang dianggap sebagai dewi kesuburan sekaligus pelindung bagi para petani. Bentuk rasa syukur terhadap Dewi Sri tersebut terekspresi pada pertunjukan kesenian tradisional. ${ }^{37}$ Sebagai contoh, pertunjukan Lengger yang merupakan kesenian tradisional yang paling populer di Kabupaten Wonosobo. Kesenian tradisional yang terekspresi dalam

\footnotetext{
${ }^{34}$ Agus Maladi Irianto, Erotika Petani Jawa Memuja Dewi ..., h. 2-3.

${ }^{35}$ Soedarsono, Tayub, Penyajian dan Tata-Tarinya (Surakarta: Sebelas Maret University Press, 1990), h. 3-7.

36Victor Turner, The Ritual Process (New York: Cornel University Press, 1986), h. 59-62.

${ }^{37}$ Agus Maladi Irianto, Erotika Petani Jawa Memuja Dewi:Tayub, Antara Ritualitas dan Sensualitas (Semarang: Lengkongcilik Press, 2005b), h. 153-154.
} 
bentuk tarian antara laki-laki dan perempuan itu, pada awalnya disikapi oleh masyarakat pendukung sebagai prosesi ritual yang berkaitan dengan masalah kesuburan.

Berdasarkan keterangan salah seorang informan, kata "lengger" berasal dari kata "leng" dan "angger" atau juga "jengger". Dalam Bahasa Jawa "leng" berarti lubang (alat kelamin perempuan) dan "angger" berarti anak laki-laki atau "jengger" (alat kelamin laki-laki). "Akan tetapi pada waktu dulu yang memainkan Lengger adalah laki-laki semua, termasuk juga untuk peran perempuan juga dimainkan laki-laki dengan berpakaian seperti perempuan", tambah informan tersebut $^{38}$ Dengan menyelenggarakan pertunjukan yang melambangkan pertemuan antara laki-laki pria (yang dipercaya sebagai benih) dan perempuan (yang dipercaya sebagai bumi atau tanah) itu, masyarakat pendukung menyikapinya sebagai bentuk pengharapan untuk mendapatkan kesuburan terhadap lahan pertanian yang kelak mereka kerjakan. Pesan kultural yang berkaitan dunia pertanian inilah yang kemudian diwariskan secara turun temurun, sepanjang orientasi hidup mereka masih bertolak dari dunia pertanian.

Pertunjukan kesenian tradisional yang disikapi sebagai proses ritual dan memuat pesan kultural berkaitan dengan kesuburan tersebut, oleh masyarakat pendukung tidak saja diselenggarakan dalam rangka aktivitas pertanian semata. Sebagai kesenian tradisional yang dipercaya memuat pesan kultural yang berkaitan dengan kesuburan perkembangannya juga diselenggarakan pada upacara perkawinan. Masyarakat pendukung mempercayai bahwa dengan menyelenggarakan pertunjukan kesenian tradisional tersebut akan berpengaruh pada kesuburan mempelai berdua, sehingga tidak lama lagi akan mendapatkan keturunan.

Bertolak dari kepercayaan tersebut, maka pertunjukan kesenian tradisional mengalami perkembangan. Ia tidak dipertunjukan hanya pada waktu yang berkaitan dengan ritual yang berkaitan dengan dunia pertanian saja, tetapi juga diselenggarakan pada sejumlah upacara perkawinan. Dengan semakin banyaknya perhelatan perkawinan yang diselenggarakan, maka frekuensi pertunjukan pun kian bertambah. Bahkan, sejumlah perhelatan yang tidak berkaitan langsung dengan pesan kultural tentang kesuburan (seperti sunatan, puputan,

\footnotetext{
${ }^{38}$ Agus Maladi Irianto, dkk, "Model-model Pengembangan Atraksi Kesenian Tradisional Wonosobo ..., h. 10-15.
} 
dan sejenisnya), ternyata juga menyelenggarakan pertunjukan kesenian tradisional. Akibat terlalu sering ditampilkan pada sejumlah acara tersebut, maka keberadaan kesenian tradisional cenderung populer sebagai pertunjukan hiburan dibandingkan sebagai prosesi ritual. ${ }^{39}$

Popularitas kesenian tradisional sebagai salah satu bentuk pertunjukan hiburan di kalangan masyarakat petani, justru mendorong kemunculan sejumlah kelompok kesenianmendapat imbalan uang (bayaran) dari si penyelenggara. Dengan ditandai bayaran tersebut maka keberadaan kesenian tradisional yang semula sebagai bagian dari prosesi ritual berubah menjadi komersial. Sebagai contoh, kesenian Jathilan yang merupakan salah satu kesenian tradisional paling populer di Kabupaten Magelang — karena di 21 kecamatan yang ada terdapat kesenian tersebut- justru lebih banyak berkembang sebagai kesenian hiburan komersial dan tidak dipertahankan sebagai kesenian ritual. Dibandingkan dengan jenis kesenian tradisional yang ada, jumlah kesenian Jathilan di Kabupaten Magelang mencapai 153 kelompok, padahal jenis kesenian tradisional yang lain rata-rata 10 kelompok. Kelompok kesenian Jathilan yang lebih mengutamakan hiburan komersial lebih banyak berada di Kecamatan Borobudur, hal itu terjadi karena wilayah ini berada di sekitar objek wisata dunia (Candi Borobudur) yang setiap saat senantiasa menyajikan atraksi wisata berupa pertunjukan kesenian Jathilan. Dengan cara mengembangkan kreativitas yang ada kesenian Jathilan di Kecamatan Borobudur telah mampu menjadi seni hiburan dan komoditi industri pariwisata di Kabupaten Magelang. ${ }^{40}$

\section{Strategi Pengembangan Kesenian Tradisional dan Tuntutan Industri Pariwisata}

Bertolak dari sejumlah uraian di atas, pada dasarnya keberadaan kesenian tradisional di era industri pariwisata mengahadapi peluang dan sekaligus tantangan. Peluang kesenian tradisional di era industri pariwisata adalah berupa kian bertambahan pemesanan untuk melakukan pertunjukan sesuai dengan tuntutan pasar. Tentu saja, dengan semakin bertambahnya pemesanan

${ }^{39}$ Agus Maladi Irianto, Erotika Petani Jawa Memuja Dewi..., h. 1-6.

${ }^{40}$ Agus Maladi Irianto, dkk., "Mengemas Kesenian Tradisional ...”, h. 45-47. 
mendorong para pelaku seni tradisional untuk senantiasa dinamis dan kreatif mengembangkan karya seninya. Dengan semakin bertambahnya pemesanan, maka diharapkan akan menambah finansial si pelaku seni tradisional. Meskipun pada uraian di atas menyebutkan bahwa adanya produksi kesenian tradisional secara massal melalui VCD dan dan DVD telah mengurangi nilai kesakralan, tetapi di sisi lain sebenarnya merupakan peluang efektif untuk mempromosikan keberadaan kesenian tradisional kepada khalayak secara luas. Apalagi mengingat bahwa kelemahan pertunjukan kesenian tradisional adalah wujudnya akan hilang begitu pertunjukan selesai. Berbeda dengan seni rupa, yang begitu selesai dicipta orang lain masih tetap bisa menikmatinya, bahkan menyimpan dalam waktu yang tidak terbatas. ${ }^{41}$

Sedangkan menyangkut tantangan perkembangan kesenian tradisional di era industri pariwisata saat ini akan lebih berpengaruh pada identitas kultural dan kearifan lokal masyarakat pendukung. Meminjam istilah Budiman, ${ }^{42}$ dampak globalisasi terutama di era industri pariwisata telah menegasi tentang budaya lokal dan menciptakan krisis eksistensial bagi masyarakat pendukung kesenian tradisional.Wajah desa pun kini berubah menjadi wajah kota, meski aspek sosial yang melingkupi masyarakat di suatu desa masih terasa kental nuansa tradisionalnya. Dampak industri pariwisata terhadap kearifan lokal suatu wilayah telah menjadi "an agent of cultural changes", baik menyangkut pengetahuan wisatawan yang melakukan perjalanan wisata, maupun endi-sendi kebudayaan masyarakat yang dikunjungi. Keduanya saling bersentuhan seiring dengan tuntutan era globalisasi.

Persentuhan kesenian tradisional dengan industri pariwisata pada dasarnya sudah menjadi keniscayaan. Apalagi sejak dicanangkannya industri pariwisata di Indonesia oleh pemerintah pada tahun 1986 lalu, maka kesenian tradisional merupakan salah satu atraksi wisata yang tujuannya untuk hiburan komersial. Presiden Soeharto waktu itu menekankan perlunya memprioritaskan sektor non-migas untuk peningkatan devisa negara, maka industri pariwisata merupakan program pemerintah yang diandalkan. ${ }^{43}$ Persentuhan

41Soedarsono, Tayub, Penyajian dan Tata-Tarinya, h. 3-7.

${ }^{42}$ Hikmat Budiman,. Lubang Hitam Kebudayaan (Yogyakarta: Kanisius, 2002), h. 37.

43Soedarsono, Seni Pertunjukan Indonesia dan Pariwisata (Bandung: MSPI, 1999), h. 3. 
tersebut menghasilkan pertunjukan wisata yang merupakan salah satu bentuk atraksi wisata. Keberadaan kesenian tradisional di era industri pariwisata, tentu saja dituntut bersaing dengan produk-produk budaya lain secara terbuka.

Kesenian tradisional yang selama ini menjadi ekspresi masyarakat pendukung untuk menciptakan keserasian antara manusia dan lingkungannya, harus menyesuaikan diri dengan kebutuhan pasar yang sejalan dengan tuntutan industri pariwisata.4 ${ }^{4}$ Berkembangnya industri pariwisata menuntut adanya komoditas-komoditas yang diharapkan bisa diperjualbelikan, yang konsekuensinya berimbas pada komodifikasi budaya. Istilah komoditas, meminjam argumentasi Jery \& Jery ${ }^{45}$ lebih merujuk pada barang yang bernilai ekonomi adalah barang yang diproduksi, dibeli, dan dijual di pasar. Sedangkan komodifikasi merupakan gambaran tentang proses barang dan jasadiproduksi dengan cepat untuk kebutuhan pasar. Tuntutan industri pariwisata yang merupakan konsekuensi logis dari dampak globalisasi ekonomi, telah menempatkan keberadaan kesenian tradisional sebagai komoditas yang kemudian harus dikomodifikasi.

Serangkaian permasalahan tersebut harus dipecahkan dengan sejumlah strategi, terutama kesenian tradisional sebagai identitas kultural dan kearifan lokal masyarakat pendukungnya tetap telindungi, tetapi ia juga diharapkan bisa mengakomodasi tuntutan globalisasi ekonomi. Berdasarkan hasil penelitian lapangan di Kabupaten Wonosobo dan Magelang, ditemukan gambaran bahwa kesenian tradisional belum mengimbangi tuntutan industri pariwisata. Hal itu terjadi karena perkembangan kesenian tradisional selama ini masih belum ada standar mutu yang memadai dalam proses produksi untuk menghasilkan produkindustri pariwisata. Untuk itulah, diperlukan strategi yang mampu menciptakan standar mutu kesenian tradisional tersebut, baik menyangkut rekomposisi, rekonstruksi, rekoreografi, dan revitaliasasi yang sejalan dengan tuntutan industri pariwisata. ${ }^{46}$

Industri pariwisata diharapkan tidak merusak keberadaan kesenian tradisional. Kendati harus direkomposisi, direkonstruksi, direkoreografi, dan

\footnotetext{
${ }^{44}$ Kuswarsantyo, “Seni Jathilan: Bentuk, Fungsi, dan Perkembangannya (1986-2013)”. Disertasi (Yogyakarta: Fakultas Bahasa dan Seni, UNY, 2013), h. 22-24. h. 94 .

45David Jery dan Julia Jery, Collins Directory of Sociology (Collins: Harper Collins Publishers, 1991),

${ }^{46}$ Agus Maladi Irianto, dkk, "Model-model Pengembangan Atraksi Kesenian Tradisional Wonosobo ..., h. 5-11. Agus Maladi Irianto, dkk., “Mengemas Kesenian Tradisional ..., h. 21-24.
} 
direvitalisasi sesuai dengan standar yang dituntut industri pariwisata, tetapi strategi pengembangannya diharapkan tetap melindungi hakikat kesenian tradisional sebagai identitas kultural dan kearifan lokal masyarakat pendukungnya. Strategi pengembangan semacam itu lazim disebut sebagai pseudo traditional art, yaknisebuah konsep dalam pengembangan kesenian tradisional dengan cara membuat tiruan bentuk aslinya. ${ }^{47}$

Strategi tersebut juga banyak dikembangkan di wilayah Bali, karena industri pariwisata di Bali merupakan kegiatan yang sangat menonjol dalam dinamika masyarakat setempat. Wisatawan yang datang ke Bali dapat menyaksikan seni tiruan pertunjukan ritual. Pengemasan seni tiruan tersebut sebenarnya sebagai strategi melindungi keaslian seni tradisional. Seperti diketahui di Bali ada tiga klasifikasi jenis pertunjukan seni, yakni wali, bebali dan balih-balihan. Pertunjukan seni kategori wali diperuntukkan pada dewa-dewi dan arwah nenek moyang, bebali adalah pertunjukan ritual untuk manusia, sedangkan balih-balihan adalah pertunjukan seni untuk hiburan masyarakat ${ }^{48}$ Atas tuntutan industri pariwisata di Bali, dikembangkanlah konsep psedo traditional art berupa tiruan seni wali dalam kemasan seni balih-balihan. Pertunjukan seni tiruan ini masih mempertahankan bentuk aslinya, tetapi nilainilai kesakralannya telah dihilangkan, durasi pertunjukannya lebih singkat atau padat, dan biayanya jauh lebih murah.

Dengan konsep psedo traditional art ini, strategi untuk mensinergikan tuntutan globalisasi ekonomi - terutama melalui industri pariwisata- dengan pengembangan kesenian tradisional dapat diterapkan. Selain itu, konsep psedo traditional art dapat melindungi eksistensi kesenian tradisional sebagai identitas kultural masyarakat pendukung, tetapi ia juga mampu mengakomodasi tuntutan globalisasi ekonomi sebagai hiburan dalam bentuk atraksi wisata. Konsep tersebut bisa berjalan dengan baik, salah satunya jika didukung dengan penyelenggaraan festival kesenian tradisional. Festival kesenian tradisional akan menjadi langkah konkret mengakomodasi tuntutan era industri pariwisata terhadap keberadaan kesenian tradisional. ${ }^{49}$ 29-31.

47Maquet, J., Introduction to Aesthetics Anthropology (Massachusetts: Addison Wesley, 1971), h.

48Soedarsono, Seni Pertunjukan Indonesia dan Pariwisata, h. 3-7.

${ }^{49}$ Kuswarsantyo, “Seni Jathilan: Bentuk, Fungsi, dan Perkembangannya (1986-2013)”. h. 17-31. 
Demikian pula seperti yang terjadi di Kabupaten Wonosobo dan Magelang, bahwa kesenian tradisional belum mampu mengimbangi tuntutan industri pariwisata dan belum ada standar mutu yang memadai, setidaknya dapat dipecahkan melalui festival tersebut. Festival yang diselengarakan secara periodik diharapkan akan menjadi salah satu langkah positif dalam rangka untuk mendukung pengembangan kesenian tradisional tersebut. Dengan melibatkan pakar seni, akademisi, dan pelaku industri pariwisata, kegiatan festival akan memberikan ruang kreasi bagi pelaku kesenian tradisional memenuhi standar mutu yang sejalan dengan industri pariwisata. Dengan adanya festival tersebut, juga dapat mengatasi persaingan kurang sehat menyangkut besar kecilnya harga pertunjukan sekaligus juga mengatasi tidak terakomodasinya penampilan kelompok kesenian yang berada jauh dari objek pariwisata. Melalui festival kesenian tradisional akan melahirkan persaingan kreatif, mendukung persebaran pertunjukan, serta mampu menciptakan kreativitas ekspresi seni secara tidak monoton.

\section{Kesimpulan}

Bertolak dari sejumlah uraian di atas, maka secara garis besar dapat disimpulkan sebagai berikut:

Pertama, komodifikasi budaya merupakan salah satu isu kontemporer yang berkembang seiring dengan pemikiran globalisasi di era pascamodernitas ini. Komodifikasi merupakan gambaran tentang proses barang dan jasadiproduksi dengan cepat sebagai komoditas untuk kebutuhan pasar. Di era ekonomi global ini, menuntut semua unsur kebudayaan dapat dijadikan komoditas, akhirnya lahirlah istilah komodifikasi budaya.Dengan kata lain, komodifikasi budaya merupakan proses produksi benda budaya sebagai komoditas yang diperjualbelikan melalui industri budaya dengan mengikuti aturan pasar.

Kedua, komodifikasi budaya kian marak berkembang di Indonesia, ditandai dengan munculnya industri pariwisata. Industri pariwisata adalah anak kandung globalisasi yang memproduksi benda budaya untuk diperjualbelikan demi keuntungan secara finansial. Salah satu bentuk benda budaya yang dikomodifikasi di era globalisasi adalah kesenian tradisional. Kesenian tradisional yang semula sebagai subjek pengetahuan, kebijakan, dan kearifan lokal masyarakat pendukungnya, berkat adanya industri pariwisata kemudian berubah menjadi objek berupa benda yang harus diperjualbelikan melalui 
proses produksi budaya. Melalui proses industri itulah, eksistensi kesenian tradisional dikemas menjadi benda budaya yang harus mengikuti aturan pasar.

Ketiga, dengan masuknya arus globalisasi ke Indonesia, kesenian tradisional menghadapi tantangan global, karena globalisasi juga merupakan bentuk penetrasi nilai baru yang melahirkan perangkat-perangkat praktis. Lahirnya perangkat-perangkat praktis yang berbasis informasi, komunikasi, dan teknologi melahirkan industrialisasi yang selalu mengarah pada orientasi pasar. Dengan kekuatan industrialistik dan kapitalistik, maka proses produksi secara massal tidak terhindarkan, termasuk mengkomodifikasi kesenian tradisional yang selama ini menjadi identitas kultural dan kearifan lokal masyarakat pendukung.

Keempat, melalui penelitian lapangan di Kabupaten Wonosobo dan Magelang Provinsi Jawa Tengah, ditemukan permasalahan bahwa kesenian tradisional belum mampu mengimbangi tuntutan industri pariwisata. Hal itu terjadi karena perkembangan kesenian tradisional selama ini masih belum ada standar mutu yang memadai dalam proses produksi untuk menghasilkan produk industri pariwisata. Untuk itulah, diperlukan adanya strategi yang mampu menciptakan standar mutu kesenian tradisional, baik menyangkut rekomposisi, rekonstruksi, rekoreografi, dan revitalisasi yang sejalan dengan tuntutan industri pawisata.

Kelima, kendati harus direkomposisi, direkonstruksi, direkoreografi, dan direvitalisasi sesuai dengan standar mutu yang dituntut dalam industri pariwisata, tetapi strategi pengembangan tersebut diharapkan tetap melindungi hakikat kesenian tradisional sebagai identitas kultural dan kearifan lokal masyarakat pendukungnya. Dengan demikian, keberadaan kesenian tradisional sebagai identitas kultural dapat terlindungi dari tuntutan komodifikasi budaya, sepanjang dikembangkan suatu konsep yang mampu mensinergikan antara persepsi dan respons masyarakat pendukung dengan tuntutan industri pariwisata tanpa harus memarjinalkan kearifan lokal.

Keenam, salah satu konsep yang paling relevan untuk mengakomodasi tuntutan komodifikasi budaya terhadap eksistensi kearifan lokal adalah konsep yang lazim disebut sebagai psedo traditional art. Konsep ini merupakan salah satu strategi dalam pengembangan kesenian tradisional, yakni dengan cara membuat tiruan dari bentuk aslinya, tetapi menghilangkan nilai-nilai kesakralan. Durasi pertunjukannya dipersingkat dan memerlukan biaya lebih murah dibandingkan pertunjukan aslinya. Dengan konsep psedo traditional art, 
eksistensi kesenian tradisional sebagai identitas kultural dan kearifan lokal masyarakat pendukungnya tetap telindungi, tetapi ia juga mampu mengakomodasi tuntutan globalisasi ekonomi sebagai seni hiburan dalam bentuk atraksi wisata.

Ketujuh, konsep psedo traditional art tersebut bisa berjalan dengan baik, salah satunya jika didukung dengan penyelenggaraan festival kesenian tradisional. Festival kesenian tradisional akan menjadi langkah konkret mengakomodasi tuntutan era industri pariwisata terhadap keberadaan kesenian tradisional. Dengan melibatkan pakar seni, akademisi, dan pelaku industri pariwisata, kegiatan festival akan memberikan ruang kreasi bagi pelaku kesenian tradisional memenuhi standar mutu yang sejalan dengan industri pariwisata. Dengan adanya festival tersebut, juga dapat mengatasi tidak terakomodasinya penampilan kelompok kesenian yang berada jauh dari objek pariwisata. Melalui festival kesenian tradisional akan melahirkan persaingan kreatif, mendukung persebaran pertunjukan, serta mampu menciptakan kreativitas bagi seniman seni tradisi di Jawa Tengah.]

\section{DAFTAR PUSTAKA}

Adorno dan Horkheimer, The Culture Industry Enlightenment as Mass Deception, London: Verso, 1979.

Agus Muriawan Putra, "Identitas \& Komodifikasi Budaya dalam Pariwisata Budaya Bali".Jurnal Analisis Pariwisata., Vol. 8, No. 2,2008.

Aris, Muhammad Shiddiq A.A., "Dampak Perekonomian Global terhadap Perekonomian Lokal", dalam http://muhammadshiddiq-aablogspot. co.id/2015/10/dampak-perekonomian-global-terhadap.html. Diunduh pada 19 Februari 2016.

Budiman, Hikmat, Lubang Hitam Kebudayaan, Yogyakarta: Kanisius, 2002.

Creswell, John W., Research Design. Qualitative \& Quantitative Approaches. USA: SAGE Publication, 1994.

Denzin, Norman K. \& Yvonna S. Lincoln, eds., Handbook of Qualitative Research, USA: SAGE Publication., 1994.

Fiske, John, Television Culture, London: Routledge. 1987. 
Gleick, Peter H., etal., The New Economy of Water: The Risk and Benefits of Globalization and Privatization of Fresh Water, California: Pasific Institute, 2002.

Irianto, Agus Maladi, "Pencarian Identitas dan Integrasi Kebudayaan pada Masyarakat Multikultural". Dipresentasikan pada Seminar Keanekaragaman Budaya Sebagai Perekat Keutuhan Bangsa Menuju Indonesia Baru. Diselenggarakan Fakultas Sastra UNDIP di Semarang, 8 September.2005.

Irianto, Agus Maladi, Erotika Petani Jawa Memuja Dewi: Tayub, Antara Ritualitas dan Sensualitas, Semarang: Lengkongcilik Press, 2005.

Irianto, Agus Maladi, "Kesenian Daerah dan Globalisasi, Sebuah Konsep Menuju Ketahanan Budaya". Dipresentasikan pada Saresehan Pengkajian Pemeliharaan dan Pengembangan Kesenian serta Kebudayaan Daerah Provinsi Jawa Tengah. Diselenggarakan Badan Kesbangpol dan Linmas Prov. Jateng di Kabupaten Kendal dan Batang, tanggal 21 \& 30 Juli, 2009.

Irianto, Agus Maladi, "Media dan Multikulturalisme" dalam Multikulturalisme Yogyakarta dan Identitas Keindonesiaan (Editor: Sri Rahayu Budiarti dan Muslimin A.R. Effendy), Jakarta: Departemen Kebudayaan dan Pariwisata Republik Indonesia, 2009.

Irianto, Agus Maladi, dkk., "Model-model Pengembangan Atraksi Kesenian Tradisional Wonosobo, Sebagai Strategi Pemahaman Wawasan Wisata Masyarakat Lokal", Laporan Penelitian, Semarang: LPPM Undip, 2010.

Irianto, Agus Maladi, "Pariwisata Jawa Tengah, Diskusi tentang Manusia dan Kebudayaan". Jurnal Ilmiah Universitas Trisakti PARIWISATA. Vol. 15 No.1, 2010.

Irianto, Agus Maladi, "Mass Media Reality In Indonesia: The Local Wisdom That Were Marginalized By The TV Broadcast". Dipresentasikan dalam The International Seminar on Education as Media of Socialization and Enculturation of Local Culture. Held by the Graduate School of Education and Human Developoment, Nagoya University, Juni 25th. 2013.

Irianto, Agus Maladi, dkk., "Mengemas Kesenian Tradisional dalam Bentuk Industri Kreatif, Studi Kasus Kesenian Jathilan", Laporan Penelitian, Semarang: LPPM Undip, 2015. 
Jery, David \& Julia Jery, Collins Directory of Sociology. Collins: Harper Collins Publishers, 1991.

Karisma, Widya \& Abidin Lating." Analisis Peran Industri Pariwisata terhadap Pendapatan Asli Daerah Kabupaten Wonosobo", Jurnal Ilmiah FEB Unibraw Karisma. No. 1 Vol. 3, 2013.

Kayam, Umar, "Seni Pertunjukan dan Sistem Kekuasaan", Jurnal Seni GELAR. Vol. 2, No. 1, 1999.

Kurniawan, Aan, "Dampak Perekonomian Global terhadap Perekonomian Domestik." dalam http://aankurniawan-astra.blogspot.co.id/2015/10/ dampak-perekonomian-global-terhadap.html. Diakses 21 Februari 2016.

Kuswarsantyo, "Seni Jathilan: Bentuk, Fungsi, dan Perkembangannya (19862013)", Disertasi, Yogyakarta: Fakultas Bahasa dan Seni, UNY, 2013.

Maquet, J., Introduction to Aesthetics Anthropology, Massachusetts: Addison Wesley, 1971.

Redfield, R., Masyarakat Petani dan Kebudayaan (terjemahan), Jakarta: YIIS, 1985.

Smith, Philip, Cultural Theory: An Introduction, Oxford \& Massachusetts: Blackwell Publishers, 2001.

Soedarsono, Tayub, Penyajian dan Tata-Tarinya, Surakarta: Sebelas Maret University Press, 1990.

Soedarsono, Seni Pertunjukan Indonesia dan Pariwisata, Bandung: MSPI, 1999.

Suara Medeka, "Sektor Pariwisata Sumbang PAD Rp 3 M", 13 Januari 2016. http://berita.suaramerdeka.com/smcetak/sektor-pariwisata-sumbangpad-rp-3-m/. Diunduh tanggal 21 Februari 2016.

Subari, "Pengaruh Pemanfaatan Lingkungan Objek Wisata Candi Borobudur terhadap Ekonomi Masyarakat di Sekitarnya", Thesis, Yogyakarta: UGM, 2007.

Suneki, Sri, "Dampak Globalisasi terhadap Eksistensi Budaya Daerah", Jurnal Ilmiah CIVIS, Vol. 2I No. 1, 2012.

Swarbrooke, J., Sustainable Tourism Management, New York: CABI Publishing is division of CAB International 1998.

Turner, Victor, The Ritual Process, New York: Cornel University Press., 1986. 